\title{
Physicochemical characterization of the soils and sediments of nine rivers draining the FIZI gold panning areas in South Kivu: environmental impact study
}

\author{
Nsambu Mukondwa Pascal, Serge Kiteba, Musibono Dieudonné, Mputu Jean-Noël
}

\begin{abstract}
The monitoring of pollution at the Fizi mining sites in the eastern part of the Democratic Republic of Congo was based on the investigation of mercury contamination in the soil of the rivers draining these sites. The objective of this work is to assess mercury pollution in the soil and sediments of rivers draining the Fizi areas through pollution indices (enrichment factor, geo-accumulation index, contamination factor, potential ecological risk factor and ecological risk index). The levels of metals (sodium, potassium, calcium, magnesium, aluminium, iron and mercury) in soils and sediments were studied in rivers and soils. The study revealed the presence of incredibly significant concentrations, particularly of mercury. Overall, our study highlighted the high levels of mercury contamination at the Fizi mining sites. And that this contamination has various origins to know anthropogenic and geological.
\end{abstract}

Keywords: Gold plating, mercury pollution, Pollution index, sediments.

\section{INTRODUCTION}

Water and soil pollution today remain a major problem for the environment, following intense human activity. Gold quarries are scattered in many territories of the province of South Kivu but most of them are more localized in the territory of Fizi. Currently, gold panning is beating the record in all the gold sites in the Fizi territory, as in those of other gold sites in developing countries in Asia (China, India, Mongolia, Korea, Indonesia, Philippines) [1], Latin America (Bolivia, Amazon) [2, 3] and Africa (Senegal, Ghana, Burkina Faso, Nigeria, Mali, Tanzania, etc.), [4-8]. Through this form of gold mining; marketable gold is extracted from its ores and concentrated through both traditional and manual methods and processes using several reagents [9]. Thus, during gold mining, mercury is generally used to extract gold from ore via the formation of the "gold-mercury" amalgam [10]. This amalgam is then heated to separate merchant gold from mercury by evaporation [11]. This practice of gold panning is responsible for the emission of mercury into the environment in the sense that the mercury vapor produced can be precipitated in the form of acid rain or can be propagated by the action of the wind and contaminate soils, plants, rivers, food chain [12]. Like surface water, the quality of the sediment and soil of the various artisanal gold mining sites in the FIZI territory must be scientifically known in order to avoid ecological and health disasters and contribute to effective and sustainable protection of the environment [9, 13]. Currently, only the work of Nsambu et al. [14-17] gives us an overview of the environmental quality of the water, soil and sediments of the gold panning sites in the Fizi territory in South Kivu in the Democratic Republic of Congo. This study focuses on the contamination of sediments and soils by mercury.

\section{MATERIAL AND METHODS}

\section{II.1. Description of the study environment}

The present research took place respectively in Lulimba, in the artisanal gold extraction zones of the Fizi territory as well as in the rivers draining them. The territory of FIZI is one of eight territories in the province of South Kivu in the Democratic Republic of Congo. Geographically, the territory of Fizi is located between $3{ }^{\circ}$ 30 'and $4^{\circ} 51^{\prime} 32^{\prime \prime}$ south latitude, $27^{\circ} 45^{\prime}$ 'and $29^{\circ} 14^{\prime} 10$ " east longitude. This territory administratively shares the borders with the territory of Uvira in the North, the territory of Mwenga and Shabunda in the West, the territory of Kalemie in the South, and Lake Tanganyika in the East [13]. 


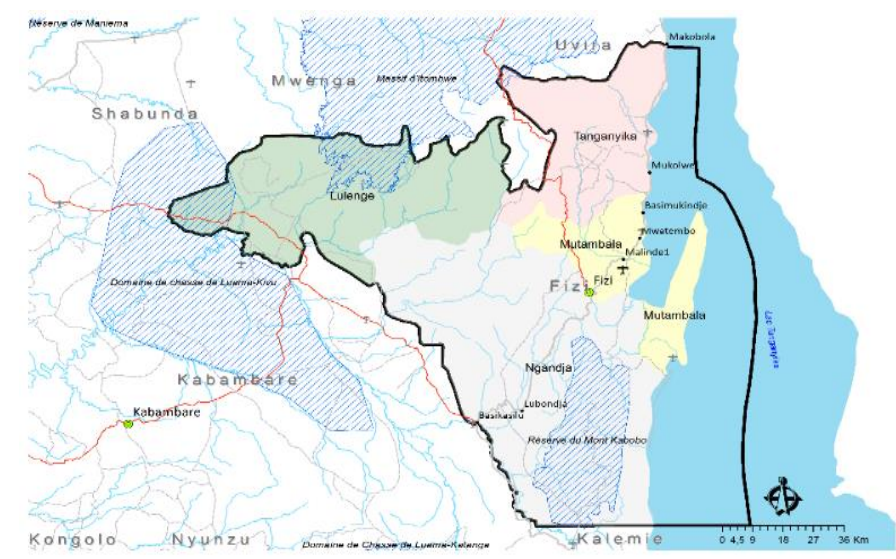

\section{Sampling}

Sediment samples were taken $0.5 \mathrm{~m}$ from the bays by driving the PVC corer into the river. The sediment core thus obtained was packed in a clean $500 \mathrm{ml}$ plastic box, previously labeled. This sampling operation was repeated twice and the constituted samples were mixed in order to form a composite sample which makes it possible to reduce the variation in the results and the uncertainty surrounding the average value obtained during the laboratory analysis of the parameters sought. The soil samples were taken at a depth of $20 \mathrm{~cm}$ by pushing the soil probe into the soil in the direction of progression of a screw from left to right while turning it in the opposite direction [15]
The following parameters were analyzed: The aluminum, mercury and iron concentration is determined by flame photometry at $530 \mathrm{~nm}[14,15]$. Calcium and magnesium are dosed by complexometry with EDTA and Eriochrome $\mathrm{T}$ black as an indicator. Potassium by emission spectroscopy. The electrical conductivity of surface water samples was determined using the conductimetric method described by Rodier [18].

\section{RESULTS AND DISCUSSION}

The results of our research are shown in Tables 1, 2, 3 and 4 which show the contents of metals (sodium, potassium, calcium, magnesium, iron, aluminium and mercury) for the sediments and soils of gold panning sites but also indices of contamination or mercury pollution (FE, Igeo, FC, FREP and IRE).

\section{Methods}

Table 1. Metal contents ( $\mathrm{Na}, \mathrm{K}, \mathrm{Ca}, \mathrm{Mg}, \mathrm{Fe}, \mathrm{Al}$ and $\mathrm{HgT}$ ) expressed in $\mathrm{mg} / \mathrm{Kg}$ of the soils of the gold panning sites.

\begin{tabular}{|c|c|c|c|c|c|c|c|c|c|}
\hline $\begin{array}{l}\text { Ground } \\
\text { Settings }\end{array}$ & Kuwa & Lubichako I & Lubichako II & Lulimba * & Makungu & Misisi & Ngalula & Nyange & Tulonge \\
\hline $\mathrm{Na}(\mathrm{mg} / \mathrm{Kg})$ & $0.8 \pm 0.0$ & $0.2 \pm 0.0$ & $0.5 \pm 0.0$ & $0.2 \pm 0.0$ & $0.6 \pm 0.1$ & $0.2 \pm 0.0$ & $0.2 \pm 0.0$ & $0.5 \pm 0.1$ & $0.6 \pm 0.1$ \\
\hline $\mathrm{K}(\mathrm{mg} / \mathrm{Kg})$ & $104.9 \pm 9.8$ & $62.9 \pm 5.4$ & $57.9 \pm 2.8$ & $52.3 \pm 2.1$ & $84.9 \pm 8.8$ & $52.1 \pm 2.3$ & $52.6 \pm 2.2$ & $70.4 \pm, 4$ & $52.6 \pm 2.3$ \\
\hline $\mathrm{Ca}(\mathrm{mg} / \mathrm{Kg})$ & $1757.3 \pm 4.1$ & $1689.5 \pm 2.2$ & $1679.1 \pm 2.2$ & $537.5 \pm 2.5$ & $1726.2 \pm 4.1$ & $1046.5 \pm 1.3$ & $1,569.1 \pm 2.0$ & $1673.7 \pm 2.3$ & $1,715.8 \pm 3.1$ \\
\hline $\mathrm{Mg}(\mathrm{mg} / \mathrm{Kg})$ & $74.5 \pm 1.6$ & $83.8 \pm 2.8$ & $87.3 \pm 2.2$ & $43.3 \pm 4.7$ & $69.2 \pm 2.1$ & $41.9 \pm 3.5$ & $42.1 \pm 3.7$ & $57.8 \pm 1.9$ & $51.8 \pm 1.3$ \\
\hline $\mathrm{Fe}(\mathrm{mg} / \mathrm{Kg})$ & $11.0 \pm 1.9$ & $5.6 \pm 0.9$ & $8.8 \pm 1.3$ & $2.0 \pm 0.1$ & $9.1 \pm 1.9$ & $4.9 \pm 0.4$ & $8.7 \pm 1.2$ & $7.3 \pm 0.9$ & $544 \pm 0.6$ \\
\hline $\mathrm{Al}$ (mg / L) & $2.7 \pm 0.2$ & $2.0 \pm 0.0$ & $2.9 \pm 0.2$ & $0.4 \pm 0.0$ & $3.2 \pm 0.2$ & $1.6 \pm 0.0$ & $2.5 \pm 0.2$ & $2.2 \pm 0.0$ & $2.5 \pm 0.2$ \\
\hline $\begin{array}{lllll}\mathrm{Hg} & \mathrm{T} & (\mathrm{mg} & / \\
\mathrm{Kg}) & & & \\
\end{array}$ & $11.6 \pm 0.2$ & $16.1 \pm 0.5$ & $13.8 \pm 0.3$ & $0.1 \pm 0.0$ & $18.4 \pm 0.6$ & $22.4 \pm 0.7$ & $8.8 \pm 0.2$ & $19.6 \pm 0.6$ & $6.9 \pm 0.1$ \\
\hline $\mathrm{CE}(\mathrm{dS} / \mathrm{m})$ & $11.7 \pm 0.3$ & $3.1 \pm 02$ & $3.0 \pm 0.2$ & $2.6 \pm 0.1$ & $7.5 \pm 0.3$ & $2.6 \pm 0.1$ & $1.1 \pm 0.0$ & $4.3 \pm 0.3$ & $2.9 \pm 0.1$ \\
\hline
\end{tabular}

The observation of these results relating to the contents of

$\mathrm{Ca}, \mathrm{Mg}, \mathrm{Al}, \mathrm{Fe}, \mathrm{Na}$ and $\mathrm{K}$ cations presented in Table 1 shows which: the soils of all the gold panning sites studied are polluted by mercury. Total mercury concentrations greatly exceed the standards of soil qualities which must be $\leq 0.5 \mathrm{mg} / \mathrm{Kg}$. The concentrations of total mercury $(\mathrm{HgT})$ in all our soils at investigation sites except the control site (Lulimba) greatly exceed the
WHO standard which fixes the threshold at $\leq 0.5 \mathrm{mg} / \mathrm{kg}$ of soil. The total mercury $(\mathrm{Hg} \mathrm{T})$ concentrations of the soils studied are listed in Table 1. The Kuwa site has an average total mercury concentration of $11.6 \pm 0.2 \mathrm{mg} / \mathrm{Kg}$ of soil, it is $16.1 \pm 0.5 \mathrm{mg} / \mathrm{Kg}$ for the soil of Lubichako I, an average of $13.8 \pm 0.3 \mathrm{mg} / \mathrm{Kg}$ for the soil of Lubichako II, it is on average $0.1 \pm 0.0 \mathrm{mg} / \mathrm{Kg}$ for the control site of Lulimba, the soil of Makungu has an average of 18.4 0.6 
$\mathrm{mg} / \mathrm{Kg}$, the most polluted Misisi soil has an average concentration of $22.4 \pm 0.7 \mathrm{mg} / \mathrm{Kg} ; 8.8 \pm 0.2 \mathrm{mg} / \mathrm{Kg}$ for Ngalula soil, $19.6 \pm 0.6 \mathrm{mg} / \mathrm{Kg}$ for Nyange soil and $6.9 \pm$ $0.1 \mathrm{mg} / \mathrm{Kg}$ for the soil of Tulonge which remains the least polluted of the others.

With the exception of our control site which is Lulimba, the rest of the sites present with a high content of metals sodium, potassium, calcium, magnesium, aluminum and iron. For example, the soils sampled on the Kuwa site presented the average calcium concentration of $1757.3 \pm$ $4.1 \mathrm{mg} / \mathrm{Kg}$, the soil of Lubichako I with $1689.5 \pm 2.2 \mathrm{mg}$ / $\mathrm{Kg}$, Lubichako II $1679.1 \pm 2.2 \mathrm{mg} / \mathrm{Kg}$, the soil of
Misisi has a content of $1046.5 \pm 1.3 \mathrm{mg} / \mathrm{Kg}$; those of the Ngalula, Nyange and Tulonge sites are respectively $1569.1 \pm 2.0 \mathrm{mg} / \mathrm{Kg}, 1673.7 \pm 2.3 \mathrm{mg} / \mathrm{Kg}$ and $1715.8 \pm$ $3.1 \mathrm{mg} / \mathrm{Kg}$. These pollutions have several causes among others we can cite: the anthropic activities exerted on each site, the geology of the sites studied, the phenomena of atmospheric deposition, the quantities of metallic mercury used in respective quarries, the phenomena of runoff, etc.

The FE ecological factor, Igeo geo-accumulation index, FC contamination factor, potential ecological risk factor FREP and the ecological risk index IRE indices were used for the environmental assessment of the sediments in the study area. The results of these indices (FE, Igeo, FREP and IRE) are presented in Table 2.

Table 2: Results relating to indices of mercury intoxication (FE, Igeo, FC, FREP, IRE) of the soils of all the rivers in the gold mining zones of Fizi according to the campaigns.

\begin{tabular}{|l|l|l|l|l|l|l|l|l|l|}
\hline $\begin{array}{l}\text { Soils } \\
\text { Settings }\end{array}$ & KUWA & LUBICHAKO I & LUBICHAKO II & LULIMBA * & MAKUNGU & MISISI & NGALULA & NYANGE & TULONGE \\
\hline FE & $22.0 \pm 0.7$ & $26.8 \pm 0.5$ & $25.2 \pm 0.4$ & $0.4 \pm 0.0$ & $28.1 \pm 0.5$ & $40.1 \pm 0.8$ & $20.1 \pm 0.8$ & $31.1 \pm 0.4$ & $19.6 \pm 0.7$ \\
\hline Igeo & $4.3 \pm 0.1$ & $4.6 \pm 0.3$ & $4.5 \pm 0.5$ & $0.7 \pm 0.1$ & $4.7 \pm 0.3$ & $4.9 \pm 0.7$ & $4.2 \pm 0.3$ & $4.8 \pm 0.4$ & $4.1 \pm 0.2$ \\
\hline FC & $6.9 \pm 0.1$ & $7.5 \pm 0.2$ & $7.3 \pm 0.1$ & $0.1 \pm 0.0$ & $7.8 \pm 0.5$ & $9.2 \pm 0.8$ & $6.7 \pm 0.0$ & $8.3 \pm 0.7$ & $6.4 \pm 0.1$ \\
\hline FREP & $170.3 \pm 3.2$ & $185.8 \pm 4.2$ & $173.3 \pm 3.2$ & $2.8 \pm 0.1$ & $191.2 \pm 0.2$ & $\begin{array}{l}207.1 \pm \\
3.4\end{array}$ & $169.3 \pm 0.2$ & $197.3 \pm 0.3$ & $165.9 \pm 3.1$ \\
\hline IRE & $494.1 \pm 2.7$ & $507.8 \pm 2.9$ & $502.4 \pm 3.1$ & $33.2 \pm 1.2$ & $518.3 \pm 3.0$ & $\begin{array}{l}585.4 \pm \\
3.6\end{array}$ & $477.6 \pm 3.6$ & $552.5 \pm 3.6$ & $470.9 \pm 2.4$ \\
\hline
\end{tabular}

The mercury enrichment factors in the soils of the sites studied (Lulimba, Misisi, Lubichako I, Lubichako II, Tulonge, Ngalula, Kuwa, Makungu and Nyangé) are listed in Table 4. We used a non-mining site as the site for reference. The soils of the Lulimba reference site (nonmining site) showed a low value of EF in mercury, an average of $0.4 \pm 0.0$ compared to the soils of other sites studied. Furthermore, the soils at the Misisi gold panning site had the highest average value of EF in mercury compared to the average values of EF in mercury from the soils of other gold panning sites $40.1 \pm 0.8$ followed successively the soils of the gold washing sites of Nyangé $31.1 \pm 0.4$, Makungu $28.1 \pm 0.5$, Lubichako I $26.8 \pm 0.5$ and Lubichako II $25.2 \pm 0,4$ whose mercury enrichment factor values are statistically identical; finally, the soils at the Kuwa, Ngalula and Tulonge sites presented respective values of $22.0 \pm 0.7 ; 20.1 \pm 0.8$ and $19.6 \pm 0.7$ with statistically similar mercury enrichment factor values.

In terms of intensity of mercury pollution from said sites, it is noted that anthropogenic enrichment in mercury was nonexistent or weak in the soils of the Lulimba reference site (non-mining site) especially as their average factor value enrichment was less than 2. In addition, anthropogenic mercury enrichment was respectively extreme in the soils of the Misisi gold panning site (because $\mathrm{FE} \geq 40$ ); very strong in the soils of the gold washing sites of Nyangé, Makungu, Lubichako I, Lubichako II, Kuwa and Ngalula (bus $20<\mathrm{FE}<40$ ); significant in the soils of the Tulonge gold panning site. The same observation is made for: the geo-accumulation index of mercury, the mercury contamination factor, the potential ecological risk factor and the ecological risk index. From this observation, it should be noted that the Misisi site remains the most polluted compared to the other gold panning sites and to our control site which is the Lulimba site as shown in Table 4. The variations in contamination indices (CI) or pollution indices (PI) of the soils studied would be due to anthropic activities carried out at each site, from the geology of the sites studied, to gold panning effluents, to atmospheric deposition phenomena, the amounts of metallic mercury used in respective quarries, runoff phenomena, etc.

Table 3. Metal contents ( $\mathrm{Na}, \mathrm{K}, \mathrm{Ca}, \mathrm{Mg}, \mathrm{Fe}, \mathrm{Al}$ and $\mathrm{HgT}$ ) expressed in $\mathrm{mg} / \mathrm{Kg}$ of the sediments of the gold panning sites.

\begin{tabular}{|l|l|l|l|l|l|l|l|l|l|}
\hline $\begin{array}{l}\text { Sediments } \\
\text { Settings }\end{array}$ & Eto ' & Kacumvi & Kimbi & Kimuti & Kuwa & Lubichako & Makungu & Mandje & Misisi \\
\hline Na (mg / & $13.8 \pm 0.2$ & $10.5 \pm 0.1$ & $26.4 \pm 0.4$ & $7.374 \pm 0.1$ & $8.6 \pm 0.2$ & $11.7 \pm 0.1$ & $12.6 \pm 0.2$ & $9.5 \pm 0.1$ & $13.8 \pm 0.1$ \\
\hline
\end{tabular}


ISSN: 2394-3661, Volume-7, Issue-5, May 2020

\begin{tabular}{|c|c|c|c|c|c|c|c|c|c|}
\hline Kg) & & & & & & & & & \\
\hline K (mg / Kg) & $\begin{array}{l}200.2 \pm \\
3.2\end{array}$ & $\begin{array}{l}185.5 \pm \\
4.0\end{array}$ & $\begin{array}{l}322.2 \pm \\
3.4\end{array}$ & $185.7 \pm 5.0$ & $\begin{array}{l}186.3 \pm \\
3.4\end{array}$ & $187.3 \pm 5.0$ & $\begin{array}{l}190.7 \pm \\
3.0\end{array}$ & $\begin{array}{l}185.7 \pm \\
3.0\end{array}$ & $\begin{array}{l}229.3 \pm \\
0.33\end{array}$ \\
\hline $\begin{array}{rll}\mathrm{Ca} & (\mathrm{mg} \quad / \\
\mathrm{Kg} & \end{array}$ & $\begin{array}{l}1630.1 \pm \\
8.2\end{array}$ & $\begin{array}{l}1726.9 \pm \\
7.7\end{array}$ & $\begin{array}{l}2,595.2 \pm \\
16.8\end{array}$ & $\begin{array}{l}1710.1 \pm \\
17.3\end{array}$ & $\begin{array}{l}1,721.8 \pm \\
9.8\end{array}$ & $\begin{array}{l}1,735.4 \pm \\
8.1\end{array}$ & $\begin{array}{l}1,732.4 \pm \\
10.9\end{array}$ & $\begin{array}{l}1,713.7 \pm \\
13.6\end{array}$ & $\begin{array}{l}1,830.6 \pm \\
6.1\end{array}$ \\
\hline $\begin{array}{l}\text { Mg (mg / } \\
\text { Kg) }\end{array}$ & $\begin{array}{l}113,2 \pm \\
5.7\end{array}$ & $94.5 \pm 2.3$ & $\begin{array}{l}183.3 \pm \\
4.7\end{array}$ & $92.4 \pm 2.4$ & $96.9 \pm 5.3$ & $98.5 \pm 7.3$ & $\begin{array}{l}102.1 \pm \\
0.3\end{array}$ & $95.9 \pm 2.3$ & $\begin{array}{l}119.5 \pm \\
4.7\end{array}$ \\
\hline Fe (mg / Kg) & $12.3 \pm 0.8$ & $7.2 \pm 0.2$ & $23.0 \pm 1.0$ & $6.8 \pm 0.1$ & $7.8 \pm 0.17$ & $9.5 \pm 0.3$ & $10.2 \pm 0.6$ & $7.9 \pm 0.4$ & $12.7 \pm 0.8$ \\
\hline $\mathrm{Al}(\mathrm{mg} / \mathrm{Kg})$ & $3.1 \pm 0.1$ & $2.8 \pm 0.1$ & $5.9 \pm 0.2$ & $2.51 \pm 0.4$ & $2.8 \pm 0.1$ & $3.0 \pm 0.0$ & $3.1 \pm 0.1$ & $2.6 \pm 0.2$ & $2.9 \pm 0.6$ \\
\hline $\begin{array}{l}\text { Hg T (mg / } \\
\text { Kg) }\end{array}$ & $33,7 \pm 0.1$ & $25.3 \pm 0.3$ & $89.8 \pm 0.9$ & $13.6 \pm 0.5$ & $19.9 \pm 0.5$ & $30.1 \pm 0.1$ & $36.9 \pm 0.4$ & $17.1 \pm 0.5$ & $41.9 \pm 0.3$ \\
\hline THIS & $12.7 \pm 0.4$ & $7.8 \pm 0.2$ & $23.4 \pm 0.2$ & $7.6 \pm 0.3$ & $8.6 \pm 0.2$ & $8.7 \pm 0.5$ & $11.5 \pm 0.5$ & $8.7 \pm 0.4$ & $12.0 \pm 0.4$ \\
\hline
\end{tabular}

The sediments of all the rivers in the gold panning sites studied are polluted by mercury. Total mercury concentrations greatly exceed the sediment quality standards which must be $\leq 0.4 \mathrm{mg} / \mathrm{Kg}$. The sediments of the Kimbi river showed the highest HgT content, $89.811 \pm$ $0.851 \mathrm{mg} / \mathrm{Kg}$ followed by the sediments of the Misisi rivers $41.9 \pm 0.3 \mathrm{mg} / \mathrm{Kg}$, Makungu $36.9 \pm 0.4 \mathrm{mg} / \mathrm{Kg}$ respectively $\mathrm{Kg}$, Etó $33.7 \pm 0.1 \mathrm{mg} / \mathrm{Kg}$, Lubichako 30.1 $\pm 0.1 \mathrm{mg} / \mathrm{Kg}$, Kacumvi $25.3 \pm 0.3 \mathrm{mg} / \mathrm{Kg}$, Kuwa $19.9 \pm$ $0.5 \mathrm{mg} / \mathrm{Kg}$, Mandje $17.1 \pm 0.5 \mathrm{mg} / \mathrm{Kg}$ ) and Kimuti 13.6 $\mathrm{mg} / \mathrm{Kg}$. The Kimbi river being the confluence of its rivers, this explains the levels observed.

For example, the sediments sampled in the Kimbi river showed the highest average concentration of sodium ions compared to those of sediments sampled in other rivers $(26.4 \pm 0.4 \mathrm{mg} / \mathrm{Kg}$ ) followed alternately sediments from the rivers Etó $(13.8 \pm 0.2 \mathrm{mg} / \mathrm{Kg})$ and Misisi $(13.8 \pm 0.1$ $\mathrm{mg} / \mathrm{Kg}$ ) whose mean values of sodium ion contents are statistically identical; Makungu (12.5 $\pm 0.3 \mathrm{mg} / \mathrm{Kg})$; Lubichako (11.7 $\pm 0.1 \mathrm{mg} / \mathrm{Kg})$; Kacumvi (10.5 $\pm 0.1 \mathrm{mg}$ / Kg); Mandje (9.5 $\pm 0.1 \mathrm{mg} / \mathrm{Kg})$; Kuwa $(8.6 \pm 0.2 \mathrm{mg} /$ $\mathrm{Kg}$ ); Kimuti $(7.4 \pm 0.1 \mathrm{mg} / \mathrm{Kg})$. The same observation is made for metals such as potassium with an average content of $322.2 \pm 3.4 \mathrm{mg} / \mathrm{Kg}$, calcium which has the content of $2595.2 \pm 16.8 \mathrm{mg} / \mathrm{Kg}$, magnesium with a concentration of $183.3 \pm 4.7 \mathrm{mg} / \mathrm{Kg}$, the iron has a concentration of $23.0 \pm 0,1 \mathrm{mg} / \mathrm{Kg}$ and aluminum with an average of $5.9 \pm 0.2 \mathrm{mg} / \mathrm{Kg}$. The least polluted river of nine remains the Kimuti as shown in Table 1.

Table 4: Results relating to indices of mercury intoxication (FE, Igeo, FC, FREP, IRE) of the sediments of all the rivers in the gold mining zones of Fizi according to the campaigns.

\begin{tabular}{|l|l|l|l|l|l|l|l|l|l|}
\hline $\begin{array}{l}\text { Rivers } \\
\text { Settings }\end{array}$ & Eto ' & Kacumvi & Kimbi & Kimuti & Kuwa & Lubichako & Makungu & Mandje & Misisi \\
\hline FE & $\begin{array}{l}24.3 \pm \\
0.5\end{array}$ & $21.4 \pm 0.3$ & $37.9 \pm 0.1$ & $19.5 \pm 0.3$ & $21.5 \pm 0.1$ & $22.5 \pm 0.3$ & $26.3 \pm 0.6$ & $20.6 \pm 0.1$ & $26.9 \pm 0.1$ \\
& $4.6 \pm 0.1$ & $4.5 \pm 0.7$ & $6.7 \pm 0.7$ & $4.2 \pm 0.4$ & $4.5 \pm 0.4$ & $4.5 \pm 0.6$ & $4.8 \pm 0.2$ & $4.4 \pm 0.2$ & $4.8 \pm 0.2$ \\
\hline Igeo & $9.4 \pm 0.5$ & $8.5 \pm 0.3$ & $14.2 \pm 0.4$ & $7.6 \pm 0.4$ & $8.1 \pm 0.1$ & $8.7 \pm 0.4$ & $9.8 \pm 0.2$ & $7.92 \pm 0.1$ & $9.9 \pm 0.4$ \\
\hline FREP & $195.4 \pm$ & $182.3 \pm 0.2$ & $\begin{array}{l}252.5 \pm \\
2.0\end{array}$ & $\begin{array}{l}166,878 \pm \\
2.5\end{array}$ & $178.4 \pm 3.2$ & $190.7 \pm 1.7$ & $202.5 \pm 4.3$ & $\begin{array}{l}173.8 \pm \\
3.2\end{array}$ & $211.6 \pm 2.8$ \\
\hline IRE & 0.3 & $544.6 \pm$ & $533.6 \pm 4.5$ & $\begin{array}{l}590.4 \pm \\
4.2\end{array}$ & $502.7 \pm 5.6$ & $\begin{array}{l}521.410 \pm \\
5.6\end{array}$ & $540.3 \pm 5.5$ & $553.6 \pm 0.4$ & $\begin{array}{l}513.0 \pm 3 . \\
4\end{array}$ \\
\hline
\end{tabular}

Results relating to mercury intoxication indices (FE, Igeo, FC, FREP, IRE) of the sediments of all the rivers in the gold mining zones of Fizi according to the campaigns shows that the Kimbi river which is our confluence remains the most polluted with mean values of $\mathrm{EF}$ Enrichment Factor $(37.9 \pm 0.1)$, of the Igeo Geoaccumulation Index $(6.7 \pm 0.7)$, the mercury contamination factor FC $(14.2 \pm 0.4)$, the potential ecological risk factor FREP (252.5 \pm 2.0$)$ and the ecological risk index IRE $(590.4 \pm 4,2)$ in sediments. The least polluted river of all the rivers studied remains the Kimuti with average values of FE $(19.5 \pm 0.3)$, Igeo (4.2 \pm $0.4)$, HR $(7.6 \pm 0.4)$, FREP $(166.9 \pm 2.5)$ and IRE (521.4 \pm 5.6 ) in sediments as shown in Table 2. These observed variations would come from anthropogenic activities, gold panning activities, quantities of metallic mercury used in respective mining quarries, phenomena of atmospheric deposition on the one hand and different gold panning effluents on the other hand.

\section{CONCLUSION}

We note that the soils and sediments analysed are of the saline type regarding the high content of sodium, magnesium, potassium and calcium observed. In addition, we were able to observe that all our sediments were polluted because they contained values higher than the values required in the standard. The sediments of all the rivers in the gold panning sites studied are polluted by mercury. Total mercury concentrations greatly exceed the sediment quality standards which must be $\leq 0.4 \mathrm{mg} / \mathrm{Kg}$. 
The soils of all the gold panning sites studied are also polluted by mercury like sediments. Total mercury concentrations greatly exceed the standards of soil qualities which must be $\leq 0.5 \mathrm{mg} / \mathrm{Kg}$.

\section{BIBLIOGRAPHY}

[1]. Basri, M.S., Koichiro Sera, Idham Andri Kurniawan., Mercury Contamination of Cattle in Artisanal and Small-Scale Gold Mining in Bombana, Southeast Sulawesi, Indonesia. Geosciences., 2017. 7(4): p. 133-143.

[2]. Maria Eugenia Garcia, O.B., Edwin Cueva, Jean R. Gimaraes., Mining and Seasonal Variation of the Metals Concentration in the Puyango River Basin-Ecuador. . Journal of Environmental Protection., 2012. 03(11): p. 1542-1550.

[3]. Roulet, M., Lucotte, M., Canuel, R, Rheaulth L, Dissolved and particulate mercury in the Tapajos River Basin, Brazilian Amazon. . The Science ofthe Total Environment., 2012. 2013: p. 203-211.

[4]. Buyun Du, P.L., Xinbin Feng, Guangle Qiu, Jun Zhou, Laurence Maurice., Mercury Exposure in Children of the Wanshan Mercury Mining Area, Guizhou, China. International Journal of Environmental Research and Public Health., 2016. 13: p. 1107-1122.

[5]. Tomiyasu, T., Kono, Y., Kodamatani, H., N. Hidayati, J. S. Rahajoe., The distribution of mercury around the small-scale gold mining area along the Cikaniki river, Bogor, Indonesia. Environmental Research., 2013. 125: p. 12-19.

[6]. P., V.S., Mercury contamination associated with smallscale gold mining in Tanzania and Zimbabwe. . The Science of The Total Environment., 2000. 259: p. 105-113.

[7]. Jacqueline R. Gerson , C.T.D., Heileen Hsu-Kim, Emily S. Bernhardt., Senegalese artisanal gold mining leads to elevated total mercury and methylmercury concentrations in soils, sediments, and rivers. . Elementa Science of the Antropocene., 2018. 6(1): p. 11-24.

[8]. Idowu Oladipo Samson, A.K.M., Osaguona Priscilla, Ajayi Joseph., Mercury contamination in artisanal gold mining area of Manyera river, Niger state Nigeria. . Journal of Environmental Research and Management., 2013. 4(9): p. 0326-0333.

[9]. UNEP, Utilisation $d u$ mercure dans l'extraction minière artisanale et à petite échelle de l'or. 2008, PNUE: Genève.

[10]. Sarah E Diringer, B.J.F., Ernesto J Ortiz, John A Gallis, Julio M Araújo-Flores, Axel Berky, William K Y Pan, Heileen Hsu-Kim., River transport of mercury from artisanal and small-scale gold mining and risks for dietary mercury exposure in Madre de Dios, Peru. Environ. Sci. Process., 2015. 17(2): p. 478-487.
[11]. R.T., L., Impacts des activités minières sur les ressources en eau en Afrique de l'Ouest: Cas des mines aurifères, Burkina Faso. AgroParisTech-ENGREF-CCRE-CEDEAO, 2012.

[12]. C. H. Lamborg, F.W.F., Damman A. W., Benoit J. M., Modern and historic atmospheric mercury fluxes in both hemispheres: Global and regional mercury cycling implications. . Global Biogeochem Cycles., 2012. 16: p. 1104-1119.

[13]. W.N., M., Territoire de Fizi-Kalembelembe, défis et développement. 2016, Paris.

[14]. Nsambu Mukondwa Pascal, M.E.A.D., Mputu Kanyinda Jean-Noël, Concentration of Total Mercury in the Blood, Urine and Hair of Gold Panners, Gold Traders, People Living in and Around Gold Panning Sites in the Territory of Fizi, DRC. International Journal of Ecotoxicology and Ecobiology., 2020. 5(1): p. 1-12.

[15]. Nsambu Mukondwa Pascal, M.E.A.D., Mputu Kanyinda Jean-Noël, Evaluation of the Level of Mercury Pollution in the Sediments of the Rivers Draining the Gold Panning Sites in the Territory of Fizi, Eastern Democratic Republic of Congo. Journal of Geoscience and Environment Protection., 2020. 8: p. 97-111.

[16]. Nsambu Mukondwa Pascal, M.E.A.D., Mputu Kanyinda Jean-Noël, Determination of the Level of Mercury Toxicity of Fish in Rivers Draining Gold Panning Sites in the Territory of Fizi, Eastern Democratic Republic of Congo. International Journal of Environmental Protection and Policy., 2020. 8(1): p. 1-10.

[17]. Nsambu Mukondwa Pascal, M.E.A.D., Mputu Kanyinda Jean-Noël, Contribution to the evaluation of the level of mercury pollution of the soils of gold mining sites in the territory of Fizi, Eastern of Democratic Republic of Congo. Journal of Materials and Environmental Sciences., 2020. 11(1): p. 85-100.

[18]. Jean Rodier, B.L., Nicole Merlet, Water analysis (natural water, waste water and sea water). $10 \mathrm{ed}$, ed. D. Technique et ingénierie. 2016, Paris: Dunod. 1824.

Nsambu Mukondwa Pascal ${ }^{1}$, Serge Kiteba ${ }^{2}$, Musibono Dieudonné ${ }^{1}$ and Mputu Jean-Noël ${ }^{3}$

${ }^{1}$ University of Kinshasa, Faculty of Sciences, Department of Environmental Sciences. BP 190 Kin XI, Kinshasa, RD. Congo ${ }^{2}$ General Secretariat for Mines, Kinshasa Gombe Democratic Republic of Congo.

${ }^{3}$ University of Kinshasa, Faculty of Sciences, Department of Chemistry and Industry. BP. 190 Kin XI, Kinshasa, DR Congo

Corresponding author: Jean-Noël MPUTU 